\title{
When a single central incisor makes the difference for human identification - a case
}

\section{report}

\author{
Quando um único incisivo central faz a diferença para a identificação humana - um relato de caso
}

Cuando un solo incisivo central marca la diferencia para la identificación humana: reporte de un

\begin{abstract}
The analysis of dental features and patterns figures amongst the primary means for human identification established by the International Criminal Police Organization (INTERPOL). Differently from fingerprint and genetic analyses, forensic dentistry does not necessarily require a minimum number of similarities between antemortem and postmortem data. In other words, human identification could be achieved from the analysis of a single distinctive tooth or even from a single dental identifier. This study aims to report a case of dental human identification of a charred body. Police investigations were carried out and narrowed the scenario towards a single victim. Fingerprints were destroyed by the fire, hence the relatives of the victim were requested to provide any antermotem dental data. A panoramic radiograph was provided. Developing third molars were visible as well as the endodontic treatment, post and core, and the nonmetallic crown of the maxillary right central incisor (tooth \#11). Postmortem radiographs were taken from the cadaver and revealed the same therapeutic dental identifiers found in tooth \#11. The observed similarities and the lack of discrepancies between antemortem and postmortem data converged to the positive identification of the victim. This study illustrated the importance of Forensic Dentistry for complex cases of human identification, such as those exposed to fire. Especial attention is driven to the possibility of safely achieving positive human identification with the contribution of a single distinctive tooth.
\end{abstract}

Keywords: Forensic dentistry; Forensic sciences; Panoramic radiography; Upper central incisor.

\section{Resumo}

A análise das características e padrões dentais figura entre os principais meios de identificação humana estabelecidos pela Organização Internacional de Polícia Criminal (INTERPOL). Diferentemente da impressão digital e das análises genéticas, a odontologia legal não requer necessariamente um número mínimo de semelhanças entre os dados antemortem e postmortem. Em outras palavras, a identificação humana poderia ser obtida a partir da análise de um único dente distinto ou até mesmo de um único identificador dental. Este estudo tem como objetivo relatar um caso de identificação humana odontológica de um corpo carbonizado. Investigações policiais foram realizadas e restringiram 
o cenário a uma única vítima. As impressões digitais foram destruídas pelo fogo, portanto, os parentes da vítima foram solicitados a fornecer quaisquer dados dentais antemortem. Uma radiografia panorâmica foi fornecida. Os terceiros molares em desenvolvimento eram visíveis, bem como o tratamento endodôntico, pino e núcleo, e a coroa não metálica do incisivo central superior direito (dente \#11). As radiografias pós-morte foram tiradas do cadáver e revelaram os mesmos identificadores dentais terapêuticos encontrados no dente \#11. As semelhanças observadas e a falta de discrepâncias entre os dados antemortem e post mortem convergiram para a identificação positiva da vítima. Este estudo ilustrou a importância da Odontologia Legal para casos complexos de identificação humana, como aqueles com exposição ao fogo. Atenção especial é dada à possibilidade de alcançar com segurança a identificação humana positiva com a contribuição de um único dente distinto.

Palavras-chave: Odontologia Forense; Ciências Forenses; Radiografia panorâmica; Incisivo central superior.

\section{Resumen}

El análisis de las características y patrones dentales figura entre los principales medios de identificación humana establecidos por la Organización Internacional de Policía Criminal (INTERPOL). A diferencia de los análisis genéticos y de huellas dactilares, la odontología forense no requiere necesariamente un número mínimo de similitudes entre los datos antemortem y postmortem. En otras palabras, la identificación humana podría lograrse a partir del análisis de un solo diente distintivo o incluso de un solo identificador dental. Este estudio tiene como objetivo informar un caso de identificación dental humana de un cuerpo carbonizado. Se llevaron a cabo investigaciones policiales y se redujo el escenario hacia una sola víctima. Las huellas dactilares fueron destruidas por el fuego, por lo que se solicitó a los familiares de la víctima que proporcionaran los datos dentales del antemotem. Se proporcionó una radiografía panorámica. Los terceros molares en desarrollo eran visibles, así como el tratamiento de endodoncia, el poste y el muñón, y la corona no metálica del incisivo central superior derecho (diente \#11). Se tomaron radiografías postmortem del cadáver y revelaron los mismos identificadores dentales terapéuticos que se encuentran en el diente \#11. Las similitudes observadas y la falta de discrepancias entre los datos antemortem y postmortem convergieron en la identificación positiva de la víctima. Este estudio ilustró la importancia de la Odontología Forense para casos complejos de identificación humana, como los expuestos al fuego. Se presta especial atención a la posibilidad de lograr de manera segura una identificación humana positiva con la contribución de un solo diente distintivo.

Palabras clave: Odontología Forense; Ciencias Forenses; Radiografía panorámica; Incisivo central superior.

\section{Introduction}

Human identification is part of the main tasks of forensic dentists (Senn \& Weems, 2013). In practice, this task is accomplished by comparing antemortem (AM) and postmortem (PM) data (Silva et al., 2017). The former is collected from dental records, while the latter is collected from the cadaver during the autopsy (Silva et al., 2015). Generally, the AM data is provided by the alleged relatives of the victim or directly by dentists that treated the victim in life (Almeida et al., 2015). The search for relatives or dentists is aided by police investigations that narrow the search from lists of missing persons (Almeida et al., 2015). The PM data, on the other hand, is obtained in the morgue from a pathway that is more straightforward - via intraand extra-oral examination (Rosario Junior et al., 2012). Photographs, radiographs and the description of visual inspection build-up a PM dossier that aims to reproduce and to be comparable with AM photographs, radiographs and written clinical findings (Carvalho et al., 2009). In theory, the AM and PM data are compared in a reconciliation process designed to assess the similarities and discrepancies between dental features (Ata-Ali \& Ata-Ali, 2014). The outcomes of this process might be positive identification, possible identification, insufficient evidences and exclusion (Queiroz et al, 2017).

Technically, the dental features analyzed during dental human identification are named identifiers and may be categorized into morphological, therapeutic and pathological (Angelakopoulos et al., 2017). The first, second and third categories are properly exemplified by peg-laterals, root canal fillings and periapical cysts, respectively. Dozens of other identifiers are known and categorized in practice (Franco et al., 2013; Franco et al., 2019). The combination of identifiers creates dental patterns that may be very distinctive, which makes forensic dentistry a reliable and scientifically acceptable method for human identification (Franco et al., 2019). However, challenging circumstances may occur when few identifiers are available. In this context, forensic dentistry stands out compared to other primary means for human identification, namely ridgeology and genetics (Interpol, 2018). More specifically, forensic dentistry enables human identification from a single distinctive identifier - without necessarily requiring a higher number of minimum similarities between AM and PM evidences 
(Silva et al, 2009).

From a human rights perspective, highlighting the role of forensic dentistry in challenging human identification cases is necessary to make to society and the dentistry community aware of the importance of retrieving the identity of the missing and unknown. This study aimed to report a case of positive identification of a charred victim by means of radiographic analysis of dental features.

\section{Methodology}

This study had a descriptive design and was presented as a forensic case report. Any personal data were omitted in order to guarantee anonymity of the involved individuals. No image was used other than radiographs with no personal information.

\section{Case Report}

\section{Preliminary medical assessment}

In 2019, two charred bodies were found in a car in Central-Western Brazil. After crime scene investigation, the bodies were sent to the local morgue for the investigation of the cause of death and identification.

The cause of death was not conclusive, but firearm projectile wounds were found in the victim's mandible. The severe carbonization did not allow additional exams such as histopathological analysis of the upper airways and carboxyhemoglobin levels. Carbonization also hampered the human identification process as it extended deeply into thoracic and abdominal organs. Hands and feet were destroyed by the fire as well, which made fingerprint analysis unfeasible.

\section{Specific dental assessment}

The dental autopsy was carried out by two forensic dentists both with more than 15 years of experience in practice. The victim's skull was partially broken, but maxilla and mandible were preserved. Visual inspection and radiographic analyses were performed. The first revealed metallic brackets with orthodontic wire on the anterior teeth and premolars of both dental arches (Figure 1). Radiographically, third molars were found unerupted and impacted in the maxilla and the mandible (Figure 2). Dental age estimation was performed and suggested mean estimated age of $17.55 \pm 1.22$ years (Gunst et al., 2003). The dental examination progressed and revealed a maxillary right central incisor (tooth \#11) with endodontic filling material, metallic post and core and aesthetic (non-metallic) crown. The other teeth did not reveal therapeutic identifiers. 
Figure 1 - Radiograph taken postmortem in occlusal view of maxilla of the victim showing the presence of orthodontic wire, brackets on the anterior teeth and premolars, as well as root canal filling and prosthetic components in the maxillary right central incisor.

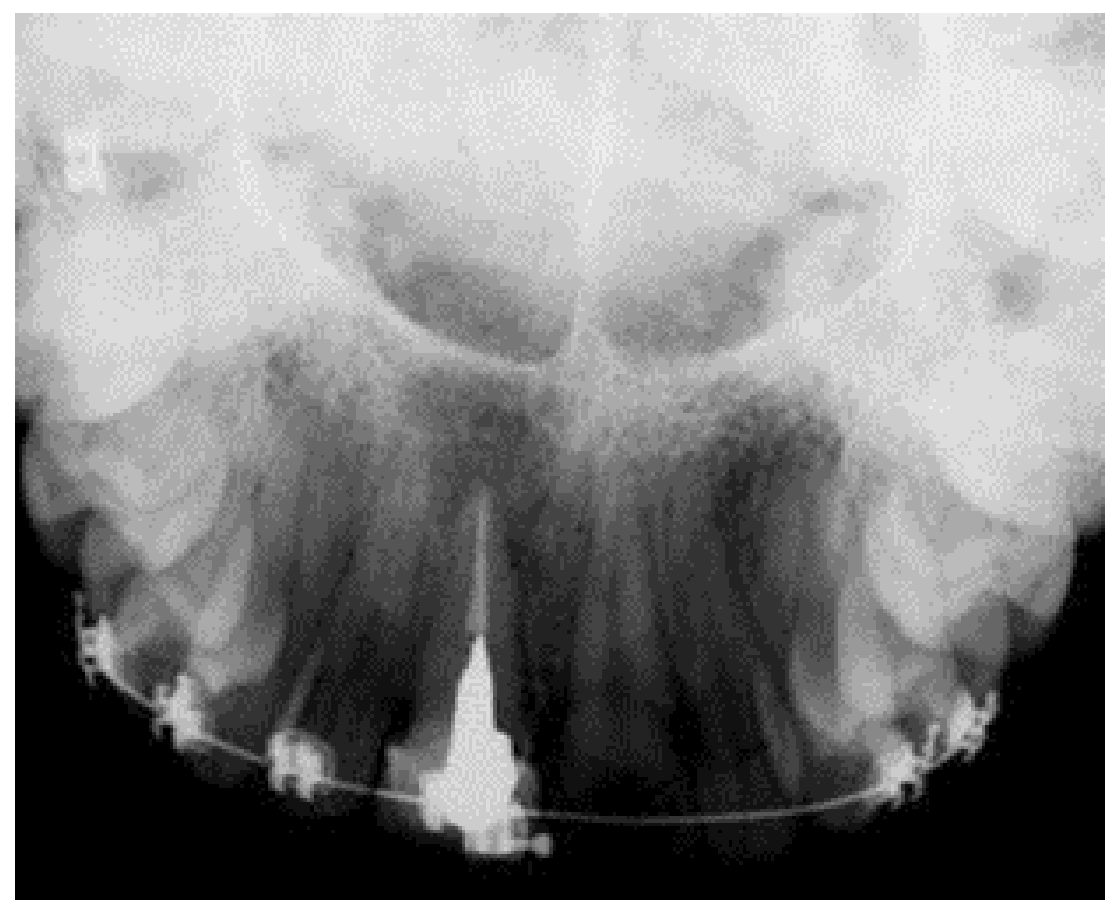

Source: Authors.

\section{Antemortem data search}

Police investigations indicated that the alleged victim was a male aged 17 years reported missing for 28 days. The potential relatives of the victim were asked to provide any type of dental or medical document to support the identification process. A panoramic radiograph dating nearly one year was provided (Figure 3). The same information found PM was found AM. The only explainable discrepancy was related to the third molars - which presented root developed at an earlier developmental stage compared to the PM radiograph. 
Figure 2 - Radiographs taken postmortem showing the right (A) and left (B) sides of the fractured mandible of the victim with orthodontic wire and brackets on the anterior teeth and premolars, as well as bilateral unerupted and impacted third molars with incomplete root development.
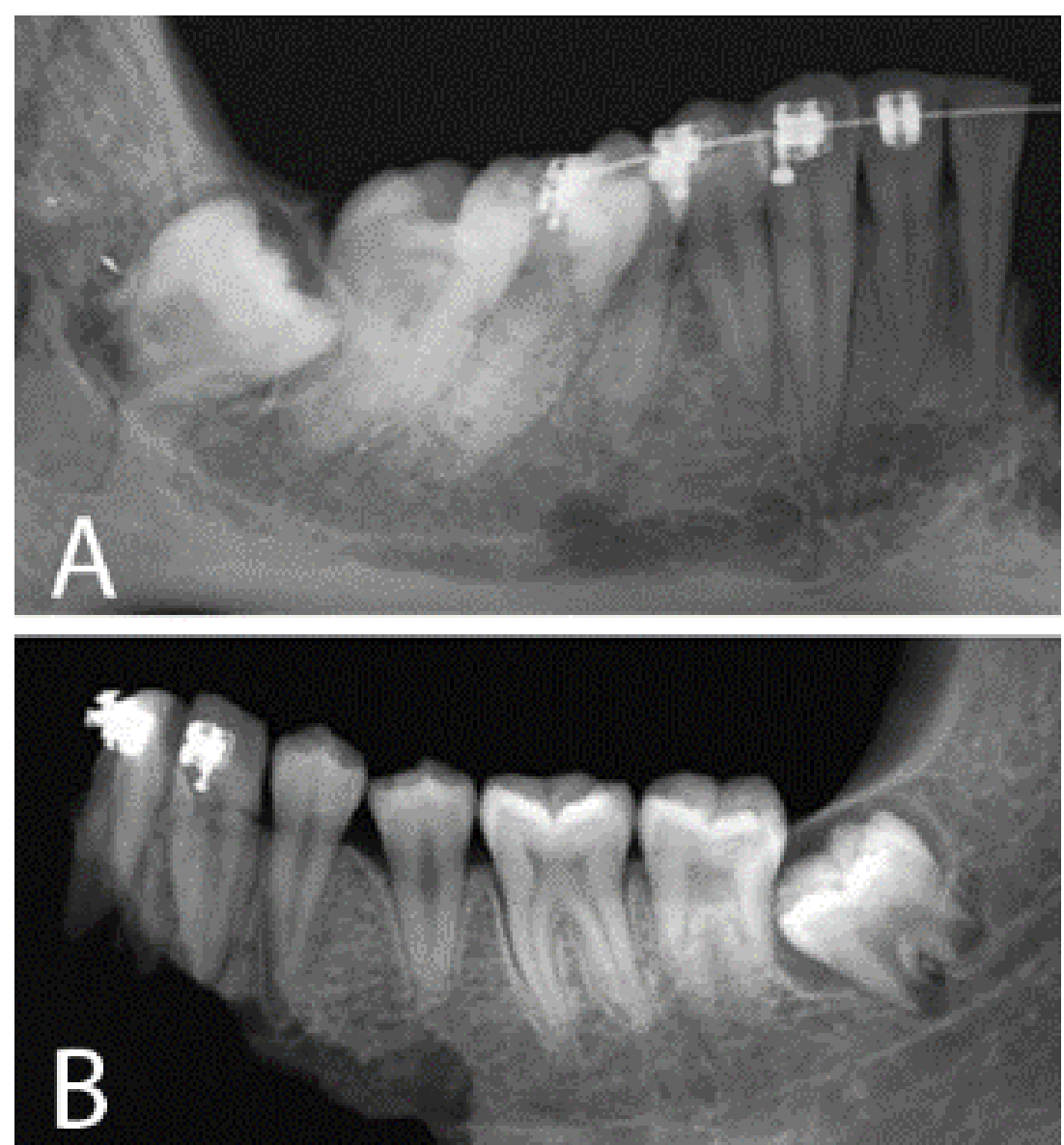

Source: Authors.

Figure 3 - Panoramic radiograph of the victim taken antemortem and provided by the alleged relatives for dental human identification. The radiograph shows the presence of all 32 teeth - four impacted third molars with incomplete root development were detected as well as root canal filling, metallic post and core and non-metallic crown in the maxillary right central incisor.

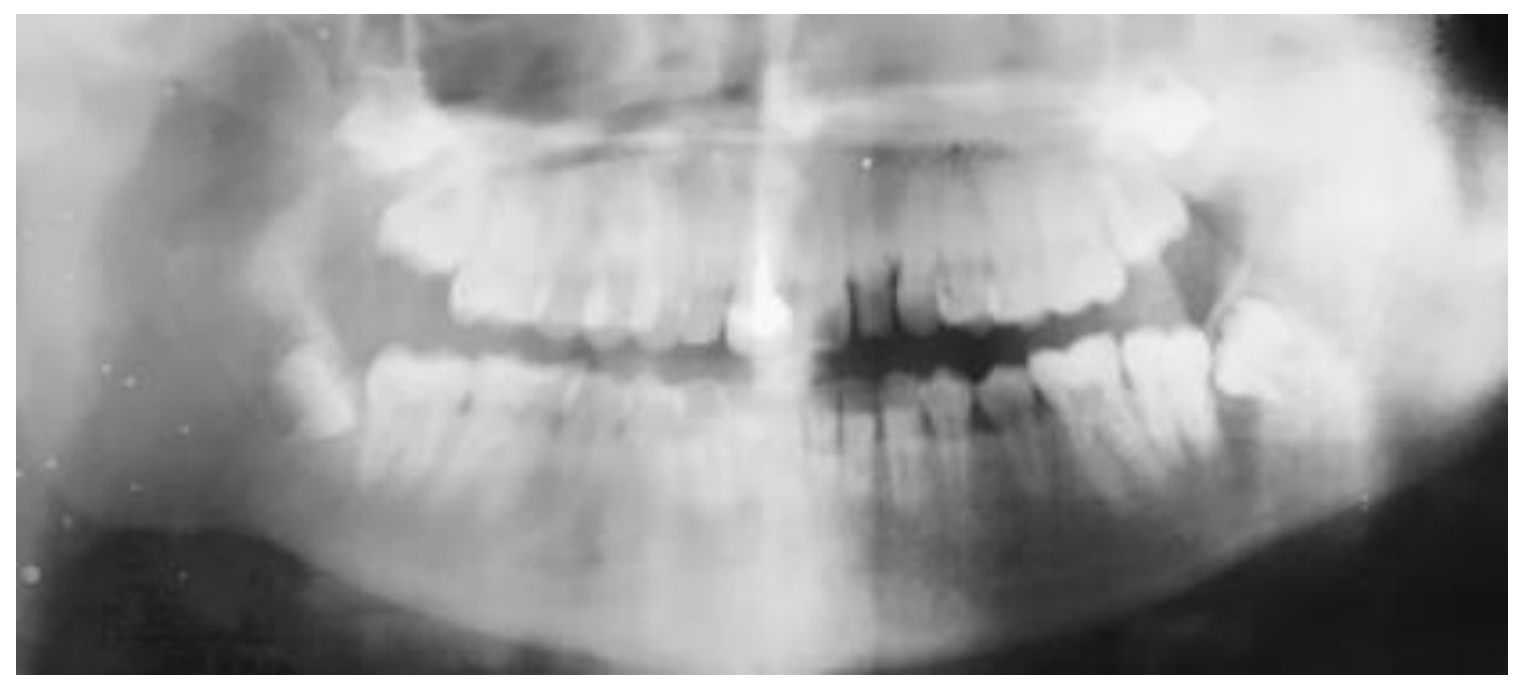

Source: Authors. 


\section{Comparative analysis}

Reconciliation was achieved by comparing and matching AM and PM identifiers (Figure 4), especially those therapeutic (i.e. root canal filling, post, core and crown) and morphological (unerupted, impacted and not completely developed third molars). Unexplainable discrepancies were not detected. Positive dental identification was established.

Figure 4 - Partial reconciliation showing the similarities between the four identifiers found postmortem (A) and antemortem (B) in the maxillary right central incisor (root canal filling, metallic post and core, and non-metallic crown). Unexplainable discrepancies were not detected.

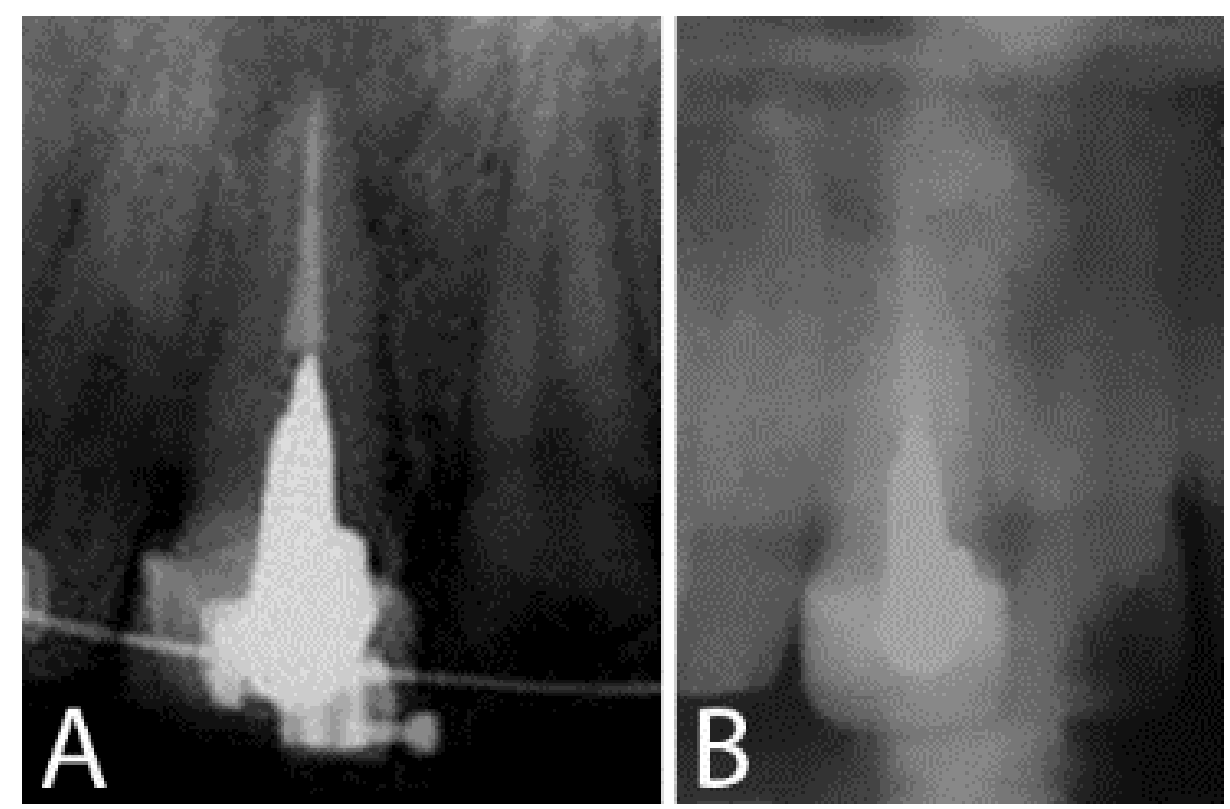

Source: Authors.

\section{Discussion}

Radiographs, computed tomography scans, and magnetic resonance imaging figure as supplementary exams that fundamental value to many fields of Dentistry (White \& Pharoah, 2013). Specific modalities and techniques for image acquisition are chosen depending on the clinical need. In Endodontics, several periapical radiographs are taken during the treatment to guide dentist's performance (Ahmed, 2015). In orthodontics, panoramic radiographs are used to have an overview of the dentomaxillofacial structures prior treatment, while lateral cephalometric and carpal radiographs are used to predict growth and design treatment planning (Isaacson et al., 2015). Forensic Dentistry, it is not different. Every single radiograph might contribute with utmost evidence for human identification. Autopsies aided by image exams are performed with more detail and access to morphological therapeutic and pathological information (Manigandan et al., 2015). Based on the exposed, this study aimed to report a case of positive human identification of a charred victim through the radiographic analysis of dental identifiers.

At first sight, the presented case might be tricky suggesting that only a single tooth (\#11) was examined and considered during the identification process. A deeper look, however, reveals that all the evidence from the available dentition was taken into account. In other words, the remaining teeth with no therapeutic identifiers were present in the mouth and their presence itself is considered an identifier (Interpol, 2018). According to Interpol, present and sound teeth are even coded (Interpol, 2018). This code is especially important in practice because it can exclude single or multiple victims with teeth missing AM - as it creates unexplainable discrepancies with teeth present PM. Present teeth, clustered within morphological 
identifiers, were registered in the present case with other morphological identifiers namely the developing unerupted and impacted third molars (Franco et al., 2019). These teeth contributed each not only as identifiers but also as parameters for dental age estimation. This case became less complex when dental age estimation narrowed the search for potential victims from a missing persons list. In mass disasters, dental age estimation has even more value in open scenarios, in which forensic labor may be drastically reduced after exclusion by age.

Other identifiers considered in this case were the root canal filling, post, core and crown all found in tooth \#11. These identifiers, clustered in the therapeutic group, were registered with other therapeutic identifiers, namely the orthodontic appliances (wire and brackets). In practice, they are quickly detected - especially in radiographs, because of their radiopaque aspect and clear representation of treatment intervention in the victim. The presence of identifiers from endodontic and orthodontic treatment in the victim corroborates the idea that Dentistry is constantly supplied with image exams in daily practice. In this context, Endodontics (Berketa et al., 2019) and Orthodontics (Picoli et al., 2019) figure as powerful sources of AM data for Forensic Dentistry. It is important to note, that dental human identification should combine all the available identifiers (Pereira \& Santos, 2013). The higher the number of matching identifiers AM and PM, the stronger and the identification report. Cases founded on single or very scarce match should be avoided unless the identifiers are very distinctive. In every situation, forensic dentists must remember that uniqueness of the human dentition is accepted in Court for human identification but not scientifically proven.

The combination of several available dental identifiers is what makes the identification process reliable and ranks forensic dentistry among the primary means for human identification. Knowing the importance of examining and registering morphological, therapeutic and pathological identifiers is a must for every forensic dentist. For optimal performances in the forensic routine, morgues and autopsy rooms should be equipped with radiologic devices, so features not found via visual inspection, such as root canal fillings, can be properly searched. In order to contribute to justice, general dentists and specialists must store and update dental records and images, and provide them when requested by Law.

The case reported in this study illustrated the dental human identification process by matching morphological and therapeutic identifiers. The charred victim identified in this study had several sound teeth present and a distinctive central incisor with four identifiers (root canal filling, metallic post and core, and aesthetic crown) with utmost contribution to human identification. Despite the relevance of the distinctive tooth, the combination of all available dental identifiers is encouraged in practice for optimal performances.

\section{Final considerations}

Differently from fingerprint and DNA analyses, human identification based on dental features does not necessarily require a minimum number of matching evidences. Efforts, however, are made to combine the highest number of evidences to support the forensic report with strong data. In certain situations, forensic odontologists will face teeth with multiple identifiers (especially when it comes to therapeutic ones). These teeth deserve especial attention because they can increase the uniqueness of the victim's dental pattern. The present study illustrates a case of a very distinctive central incisor that contributed (together with other findings) for dental human identification.

\section{References}

Ahmed, H. M. A. (2015). Guidelines to enhance the interpretation of two-dimensional periapical radiographic images in endodontics. Eur J Gen Dent, 4, 106112. http://doi.org/10.4103/2278-9626.163320 
Angelakopoulos, N., Franco, A., Willems, G., Fieuws, S., \& Thevissen, P. (2017). Clinically detectable dental identifiers observed in intra-oral photographs and extra-oral radiographs, validated for human identification purposes. J Forensic Sci, 62, 900-906. http://doi.org/10.1111/1556-4029.13310

Ata-Ali, J., \& Ata-Ali, F. (2014). Forensic dentistry in human identification: A review of the literature. J Clin Exp Dent, 6, 162-167. http://doi.org/ https://dx.doi.org/10.4317\%2Fjced.51387

Berketa, J. W., Sims, C., \& Rahmat, R. A. A. B. (2019). The utilization of small amounts of residual endodontic material for dental identification. J Forensic Odontostomatol, 37, 63-65.

Carvalho, S. P. M., Lopes-Junior, C., \& Peres, A. S. (2009). Use of images for human identification in forensic dentistry. Radiol Bras, 42, 125-130. http://doi.org/10.1590/S0100-39842009000200012

Franco, A., Orestes, S. G. F., Coimbra, E. F., Thevissen, P., \& Fernandes, Â. (2019). Comparing dental identifier charting in cone beam computed tomography scans and panoramic radiographs using Interpol coding for human identification. Forensic Sci Int, 302, 109860. http://doi.org/10.1016/j.forsciint.2019.06.018

Franco, A., Thevissen, P., Coudyzer, W., Develter, W., Van De Voorde, W., Oyen, R. et al. (2013). Feasibility and validation of virtual autopsy for dental identification using the Interpol dental codes. J Forensic Leg Med, 20, 248-254. http://doi.org/10.1016/j.jflm.2012.09.021

Gunst, K., Mesotten, K., Carbonez, A., \& Willems, G. (2003). Third molar root development in relation to chronological age: a large sample sized retrospective study. Forensic Sci Int, 136, 52-57. http://doi.org/10.1016/s0379-0738(03)00263-9

INTERPOL. (2018). Disaster victim identification guide. International Criminal Police Organization, Lyon.

Isaacson, K. G., Thom, A. R., Atack, N. E., Horner, K., \& Whaites, E. (2015). Orthodontic radiographs: Guidelines for the use of radiographs in clinical orthodontics. 4th ed. British Orthodontic Society, London.

Manigandan, T., Sumathy, C., Elumalai, M., Sathasivasubramanian, S., \& Kannan, A. (2015). Forensic radiology in dentistry. J Pharm Bioallied Sci, 7, 260264.

Pereira, C. P., \& Santos, J. C. (2013). How to do identify single cases according to the quality assurance from IOFOS. The positive identification of an unidentified body by dental parameters: a case of homicide. J Forensic Leg Med, 20, 169-173. http://doi.org/10.1016/j.jflm.2012.06.004

Picoli, F. F., Mundim-Picoli, M. B. V., Rodrigues, L. G., Silva, M. A. G. S., Franco, A., \& Silva, R. F. (2019). Dental cingulum and position of fixed orthodontic appliance as source of morphological and therapeutic identifiers: an unusual case report. J Forensic Dental Sci, 11, 51-55. http://doi.org/10.4103\%2Fjfo.jfds_28_19

Queiroz, C. L., Bostock, E. M., Santos, C. F., Guimarães, M. A., \& Silva, R. H. A. (2017). A forensic identification case and DPid - can it be a useful tool? J App Oral Sci, 25, 346-353. http://doi.org/10.1590/1678-7757-2016-0175

Rosário Junior, A. F., Souza, P. H. C., Coudyzer, W., Thevissen, P., Willems, G., \& Jacobs, R. (2012). Virtual autopsy in forensic sciences and its application in the forensic odontology. Rev Odont Cienc, 27, 5-9. http://doi.org/10.1590/S1980-65232012000100001

Senn, D. R., \& Weems, R. A. (2013). Manual of forensic odontology. (4th ed.), CRC Press, Boca Raton.

Silva, R. F., Franco, A., Souza, J. B., Picoli, F. F., Mendes, S. D., \& Nunes, F. G. (2015). Human identification through the analysis of smile photographs. Am J Forensic Med Pathol, 36, 71-74. http://doi.org/10.1097/PAF.0000000000000148

Silva, R. F., Picoli, F. F., Botelho, T. L., Resende, R. G., \& Franco, A. (2017). Forensic identification of decomposed human body through comparison between ante-mortem and post-mortem CT images of frontal sinuses: case report. Acta Stomatol. Croat, 51, 227-231. http://doi.org/10.15644/asc51/3/6

Silva, R. F., Prado, M. M., Oliveira, H. C. M., \& Daruge Junior, E. (2009). How many points of concordance are necessary to obtain a positive forensic dental identification? Rev Odontol UNICID, 2, 63-68.

White, S., \& Pharoah, M. (2013). Oral radiology: principles and interpretation. (7th ed.) Mosby, Maryland Heights. 